\title{
The Role of Serotonin in the Regulation of Motor Function of the Upper Digestive Tract in Normal and Pathological Conditions
}

\author{
Puzikov AM* \\ GBIH Moscow Clinical Scientific Center Department of Health Moscow, Russia \\ *Corresponding author: Puzikov AM, GBIH Moscow Clinical Scientific Center Department of Health Moscow, Russia
}

\begin{tabular}{|c|c|}
\hline ARTICLE INFO & ABSTRACT \\
\hline Received: 㗀 July 03, 2019 & Citation: Puzikov AM. The Role of Serotonin in the Regulation of Motor Function of the \\
\hline Published: 幽 July 10, 2019 & $\begin{array}{l}\text { Upper Digestive Tract in Normal and Pathological Conditions. Biomed J Sci \& Tech Res } \\
\text { 19(3)-2019. BJSTR. MS.ID.003312. }\end{array}$ \\
\hline
\end{tabular}

\section{Introduction}

In the esophagus and stomach, serotonin is present in the neurons of the enteric nervous system and extraorgan serotonergic neurons and fibers [1-4], which regulate the motor function of these organs. In addition, serotonin is contained in platelets, mast cells and macrophages and may appear extracellularly under conditions of pathology. It is important to investigate the effect of serotonin on the motor function of hollow organs, both in functional conditions and in pathology. The aim is to investigate the role of serotonin in the regulation of motor function of the esophagus and stomach in functional conditions and in the simulation of gastroesophageal reflux (GER). Materials and methods. The experiments were carried out on 32 Wistar rats weighing 240-270 g under nebutal anesthesia (40 mg / kg intraperitoneally). An upper median laparotomy was carried out, bipolar silver electrodes were applied to the cardiac section of the stomach and the lower third of the esophagus to record the electromyogram (EMG).

Serotonin adipinate was administered at a dose of $100 \mathrm{mg} / \mathrm{kg}$ intravenously and its effect on the motor function of the esophagus and stomach of group 1 animals was examined $(n=16)$. The GER model was created by injecting $0.1 \mathrm{ml}$ of methylene blue into the cardiac section of the stomach and administering serotonin to animals of the 2 nd group against this background $(n=16)$. It was noted staining of the lower third of the esophagus, indicating the development of GER. Slow-wavelength EMG activity and power of tonic contractions were recorded. Statistical processing was carried out using the software package Statistica-17. Results. The frequency of slow waves of the esophagus with the introduction of serotonin was $19.0 \pm 4.0$ to $23.0 \pm 4.5 / \mathrm{min}$ (an increase of $21.1 \% \mathrm{p}$ $<0.05$ ), the amplitude from $0.15 \pm 0.02$ to $0,18 \pm 0.03 \mathrm{mV}$ (increase by $20 \% \mathrm{p}<0.05$ ), power of tonic contractions from $2.85 \pm 0.21$ to $4.14 \pm 0.33$ (increase by $43.9 \% \mathrm{p}<0.05$ ). The frequency of slow gastric waves with the introduction of serotonin increased from $9.1 \pm 0.3$ to $11.3 \pm 0.6 / \mathrm{min}$ (an increase of $24.2 \% \mathrm{p}<0.05$ ), the amplitude from $0.12 \pm 0.03$ to $0.22 \pm 0.04 \mathrm{mV}$ (increase by $83.3 \%$ $\mathrm{p}<0.05$ ), power of tonic contractions from $1.092 \pm 0.21$ to $2.486 \pm$ 0.33 (increase by $127.6 \% \mathrm{p}<0.05$ ) .

Thus, the introduction of serotonin leads to a pronounced stimulatory effect on the motor function of the esophagus and stomach. The introduction of methylene blue followed by the introduction of serotonin changed the frequency of slow waves of the lower third of the esophagus - it increased 1.8 times ( $p<0.01$ ), amplitudes 1.1 times ( $p<0.01$ ), the power of tonic contractions was $3.893 \pm 0.23$ (an increase by $35.5 \% \mathrm{p}<0.05$ ). Thus, the introduction of methylene blue, as a donor of nitric oxide, leads to relaxation of the lower esophageal sphincter. The subsequent activation of retrograde motor activity of the smooth muscles of the stomach by serotonin leads to the development of GER. Findings. The study showed that serotonin stimulates the motor function of the esophagus and stomach in both antegrade and retrograde directions. Serotonin has a pronounced effect on the development of GER.

\section{References}

1. Camilleri M, Kerstens R, Rykx A, Vandeplassche L (2008) A PlaceboControlled Trial of Prucalopride for Severe Chronic Constipation. N Engl J Med 358(22): 2344-2354. 
2. Tack J, van Outryve M, Beyens G, Kerstens R, Vandeplassche L (2009) Prucalopride (Resolor) in the treatment of severe chronic constipation in patients dissatisfied with laxatives. Gut 58: 357-365.

3. Pavone LM, Tafuri S, Lo Muto R, Spina A, Lychkova AE, et al. (2009) Expression of the serotonin transporter SERT in the genital tract of cattle. Regul Pept 154(1-3): 1-4.

\section{ISSN: 2574-1241}

DOI: 10.26717/BJSTR.2019.19.003312

Puzikov AM. Biomed J Sci \& Tech Res

(C) This work is licensed under Creative

Submission Link: https://biomedres.us/submit-manuscript.php
4. Cinca R, Chera D, Gruss HJ, Halphen M (2013) Randomised clinical trial: macrogol/PEG 3350+electrolytes versus prucalopride in the treatment of chronic constipation - a comparison in a controlled environment. Aliment Pharmacol Ther 37(9): 876-886.

BIOMEDICAL
RESEARCHES $\quad \begin{aligned} & \text { Assets of Publishing with us } \\ & \text { - Global archiving of articles } \\ & \text { ISSN: } 2574-1241\end{aligned}$

